\title{
Educational Values Derived from the Provisions of the Sanctions in the Holy Quran and the Prophet's Sunnah
}

\author{
Marwa Salem Nouri \\ Iraq - Ministry of Higher Education and Scientific Research -DiyalaUniversity - Faculty of Education for Pure
} Sciences

\begin{abstract}
The problem of research: The problem of research lies in answering the following question: What are the educational values derived from the penal provisions in the Holy Quran and the Prophet's Sunnah?The importance of research: The importance of study ing is shown by the following:To show the extent to which Islam is concerned with the provisions of the sanctions.Disclosure of jurisprudential rulings and educational values relating to the provisions of punishment, for their practice in public and private life, such as: (such as adultery, ejaculation, drinking, theft and apostasy), as well as retribution, such as murder, manslaughter and semi-intentional homicide. The current study gives a new addition to the Iraqi Library in the field of education philosophy. The objective of the research: The current research aims to reveal the educational values derived from the provisions of the sanctions in the Holy Quran and the Prophet's Sunnah.

Search limits: Current search is determined by the following:
\end{abstract}

Article Received: 16th October, 2020; Article Revised: 30th December, 2020; Article Accepted: 08th January, 2021

one is weak, you must cover one's own, or sincere repentance to God for doing it.

4. Raising individuals, educating them, and making them aware that the punishment of the offender is his mercy, discipline for his crime, reform ing himself, and cleansing of his sins.

5. Raising individuals to take care of people's lives, and not to use violence and murder in their treatment of the extreme inviolability of a Muslim.

6. Raise individuals on dignified treatment, keeping the tongue from ejaculation, even if it is a slave.

7. Raising individuals, educating them, and training them that Allah almighty has set different punishments for each sin according to its harm to the individual and society, and at the expense of the offence, so that it is a deterrent and a deterrent against repeating it.

8. Raising, educating and training individuals on the importance of equality among people;

9. Awareness of individuals the existence of atonement for certain sins committed by man.

10. Educate individuals that setting up the limit is atonement.
1. Statement of jurisprudence and educational values related to penal provisions, such as:

A- Limits, such as: (adultery limit, libel limit, robbery limit, apostasy limit).

B- Retribution, such as: (murder, manslaughter).

2. Relying on Qur'anic verses and prophetic hadiths.

3. Relying on the mothers of the jurisprudential books, which dealt in detail with explanation and detail on the subject of the provisions of the sanctions.

Research methodology: The descriptive and inference method was used to achieve the research objective.

Presentation and interpretation of the results: The study reached the following results:

1. To raise individuals and train them to establish god's limits, by defining the punishment of each sin, large and small, in order to avoid it.

2. Raising, training and introducing individuals to the purposes of Islamic law is one of the five necessities: (preservation of religion, self, mind, offspring, money).

3. Educate individuals and train them to avoid falling into the big ones, and if 
The Prophet's Sunnah also urged the right to avoid sins, to limit the perpetrators of crimes, and to do justice among the people, such as what was said about the Prophet: (The blood of a Muslim man is not solved except by one of three, a man who is adulterous after his horseship, he must be stoned) (steam) 1987: 6878), said ((("Do not cut off the hand of the thief except in a quarter of dinars onwards") (Bukhari, 1987: 6789), (Muslim, D.T:1684), said () (If Fatima bint Muhammad had done so, i would have cut her hand, 1987: 4304) (Ibn Hazm, D.T., C11:358) and his saying (Al-Muqasi, 1987: 4304), (Ibn Hazm, D.T., C11:358) and saying ((Al-Muqasi, 1987: 4304), (Ibn Hazm, D.T., C11:358), and his saying ((Al-Muqasi) God has the platforms of Light on the right of rahman, and both hands are right, who modify their rule, their family and what they have to do) (Muslim, D.T., C3: 1458); In all its circumstances, taking care of the interests of Muslims and stabilizing their conditions, it was only natural that Islamic law should include punishments for the perpetrators of crimes against society, and cause its disintegration and disorder, and the evidence confirming the legitimacy of the punishments in Islam has been combined in the Book of Allah Almighty, Peace be upon him

We conclude from the above that the punishment in Islam is part of a divine system that Allah has given to the Prophet Muhammad, to be a system that guarantees those who follow it safety, stability and happiness to the Day of Resurrection, Peace be upon him

The basis of punishment in Islam is that it is an officer that preserves the balance between the rights of the individual and the community together;

1. To show the extent to which Islam is concerned with the provisions of the sanctions.

2. Disclosure of jurisprudential rulings and educational values relating to penal provisions, for their practice in
In the light of the results of the research, the researcher came up with a set of recommendations and proposals.

Search problem:

The government has also taken a number of measures to address the problem of the use of force by the police, which has been used to prevent the use of force. The weakness of the individual's religious disloyalty and the abandonment of the true faith in God help to spread all types of crime, because the weakness of religious disloyalty weakens the human soul, loses its immunity, and the devil can become a prisonerof his own desires anddesires.

Despite the state's application of positive sanctions against criminals, crime rates have begun to increase, so it is necessary to reveal the types of punishments in the Qur'an and the Prophet's Sunnah, and the educational values it contains, in order to contribute to reducing crime of all kinds among members of society, in order to return security, reassurance and justice in society;

What are the educational values derived from the provisions of the sanctions in the Qur'an and the Prophet's Sunnah?

\section{The importance of research:}

The Holy Qur'an is the source of Islamic law, as it is the status of the constitution governing the life of the Muslim nation, and the punishment in the Holy Qur'an has been characterized by softness at times, and severity at other times, because of its great influence in social life, so God has prescribed punishments, in support of his approach to the earth, and the protection of individuals and the Islamic society from Losing their money, spilling their blood, or violating their symptoms, preserving the cohesion of the community, spreading security, peace, justice, and chastity among them (Kilani, 2014:92) The punishment in Islam came to reform society and spread mercy inMuslims. 
and retribution from (intentional murder, manslaughter).

2. Inference: He knew him (Ibn Mansoor, 1423 Ah) as:"Extraction, or the extraction of jurisprudence, by extracting the jurisprudence with his diligence and understanding" (Ibn Masrif, 1423 Ah, c. $8: 433)$.

3. Verdict: Linguistically: He knew him (Al-Razi, 1983) as: "The judiciary, and they have (ruled) among them (ruling), and (ruling) him and his sentence, and also the wisdom of science" (Al-Razi, 1983: 148). Judgment: He knew him (according to God, 1976) as: "God's speech concerning the actions of those charged with necessity, choice, or status" (According to God, 1976:375).

4. Punishment: Punishment linguistically: Defined (Ibn Mansoor, 1423 $\mathrm{Ah})$ as: "Who is punished, or punished for his guilt, and for his guilt to take him with him, and to arrest the man: if you sanction him well, and punish him; i.e., his gaze is evil" (Ibn Mansoor, 1423 Ah, c. 1:619). Punishment is a term: (Al-Mardi, 2006) defines it as: "The borders and marriages were set by Allaah, in order to deter the commission of what is forbidden and to leave what is forbidden and leave what is forbidden for the greed of the desires of the other with the urgency of the feast of pleasure;

5. The Prophet's Year: Defined (AlSibai, 1982) as: "What influenced the Prophet () to say, act, report, or moral or moral character, whether before or after the mission" (Al-Sibai, 1992:47).Peace be upon him

\section{Research methodology:}

According to the nature of the research, the descriptive and inference approach was used in achieving the objective of the current research, and the inference approach is: "The method based on the consideration of texts or sayings, studying, analysing, and attempting to extract the provisions, sermons, and secrets" (Al-Dhuwayand al-Rasheed, 1432 Ah: 25). public and private life, such as adultery, slander, drinking, apostasy and theft, as well as retribution, such as murder, manslaughter and semi-intentional homicide.

3. The current study gives a new addition to the Iraqi Library in the field of education philosophy.

Search goal:

The current research aims to reveal the educational values derived from the provisions of the sanctions in the Holy Quran and the Prophet's Sunnah.

Search limits:

The current research is determined by:

1. The provisions of the punishments in the Holy Qur'an and the Prophet's Sunnah, which are imposed on the following crimes:

A- Limits, such as: (adultery limit, libel limit, robbery limit, apostasy limit).

B- Retribution, such as: (murder, manslaughter).

2. To rely on the Qur'anic verses collected, to analyze them, and to derive them from a deliberate sample of qur'anic verses governing the provisions of the sanctions, which amounted to 29 verses.

3. Relying on the prophetic hadiths collected, graduated, and analyzed from a deliberate sample of prophetic hadiths governing the provisions of the sanctions contained in the Prophetic biography, the number of (15) recently.

Select terms:

1. Educational values: Defined (AlAbadi, 2004): "Provisions that are called desirable, or preferred, according to community standards and community culture, based on individuals' experiences, interaction with judgments, and attitudes where alternatives to those provisions are available" (Al-Abadi, 2004: 72 Educational values in current research are referred to as: educational content (attitudes, principles, and educational values), which includes the jurisprudential provisions on punishments such as adultery, libel limit, theft limit, apostasy, 
imposing sanctions in Islam are for individuals and society to enjoy security, stability and justice (Al-Ghazali, $1413 \mathrm{H}$ ). Therefore, the researcher reached out to the educational values derived from the provisions of the sanctions in the Holy Qur'an and the Prophet's Sunnah: Peace be upon him

1. Raising individuals and training them to establish the limits of God by defining the punishment of each sin, large and small, so as to avoid it, as well as urging the Prophet to abide by the limits of Islam, he said: ((God almighty imposes decrees do not waste them, and limits do not be used, and forbid things so You violate them, and shut up about things of mercy to you without forgetting, don't look for them)) (Ibn Kabir, 1401, c3:202), alMordi said: "Borders and marriage sought by Allah almighty to deter them from committing what is forbidden and leaving what is forbidden" (Al-Mardi, 2006). 288), to prevent the unsub from returning to the likes of his act and the scareof others. We conclude from the foregoing that Islamic law is a mercy, not a strict border; Peace be upon him

2. Raising individuals, educating them, and introducing them to the purposes of Islamic law are among the five necessities: (keeping religion, self, mind, offspring, and money) and the Prophet urged () to abide by the five necessities; And don't kill your children from the sins, and don't bring a fad that you will miss in your hands and legs, and don't disobey me in a favour; Allah, if he wills punish him, and if he wishes to pardon him) he said, "I sold him for that" (Ibn Qadama, 1983, c. 1:376).Peace be upon him Peace be upon him

3. Educating individuals and raising them to avoid falling into the greats, and if one is weak, he must cover one's self and repent sincerely to God for doing so; he also urged the Prophet to avoid falling into the majors; Peace be upon him
The inference approach has been followed as follows:

1. The researcher collected the Qur'anic verses concerning the provisions of the sanctions, divided them, and arranged them on the axes of the study, and the number of verses (29) was reached.

2. Collecting, graduating, dividing, and downloading the prophetic hadiths, which have recently reached 15 .

3. Collecting the conditions of the correct punishment provisions from the books of scholars, and deriving some of these conditions from the words of the interpreters in the examples.

4. The researcher used the application and cited examples, for theoretical rooting, in the research without being separated by a separate section, because it would clarify theoretical issues more and avoid repetition.

5. The researcher documented the scientific material in the current research as follows:

A- Attributing the verses in the research to its citizens in the Holy Qur'an.

B- Graduation of the prophetic hadiths contained in the research from the sources of the year adopted by mentioning the sources, the part, the page, and the number of hadiths, if any.

C- Documenting the words conveyed by scientists by referring to their positions in the research in a brief definition.

View and interpret the results: conclusions:

The study reached the following

The Penal Code in Islam revolves around achieving the purposes of Islamic law, which is to protect the public interest, to preserve the five necessities, and to preserve the human being's religion, self, width, money, mind, and crime is an assault on one of these things; adultery is an attack on the offspring, and Theft is an attack on money, drinking alcohol is an attack on the mind, apostasy is an attack on religion, and the prophet's cause is an attack on him, if the legitimate purposes of 
cuts off his hand, steals the rope and cuts his hand) (Bukhari, 1987). 6783), (Ibn Hazm, D.T., C11:356); He said: (Shirk by God, magic, and killing the soul that God has forbidden except by truth, eating riba, eating the orphan's money, taking over the day of the crawl, and tossing the fortified believers who are oblivious)) (Bukhari, 1987: 2766), (Muslim, D.T.: 89), (Abu Dawood, D.T.: 2874).Peace be upon him .

8. Raising individuals, educating them and educating them about the importance of equality among people; The Prophet urged the application of equal punishment salvo on people. 4304), (Ibn Hazm, D.T., C11: 358). Peace be upon him

9. He urged the Prophet to leave sins and sins Ramadan; He said: No, he said: (Feed Steen Poor) (Son of Adma, 1997, c4:381).Peace be upon him

10. To educate individuals that the limit is expiation for him, and the Prophet urged him to establish the limit, as he says: (Ba'ayni, do not share anything with God, do not steal, do not weigh, do not kill your children, and do not come with a fad that you will lose in your hands and Your legs, and don't disobey me in a favour, who ever fulfilled his reward to Allah, and whoever has done something to you, he has atonement, and whoever has done anything, and then God will cover him, and he will, if he will, and if he will punish him) (Bukhari, 1987) 18), (Muslim, D.T.: 1709), (Termadi, DT: 1439), (Feminist, 1991: 4178).Peace be upon him

We conclude from the above that the purpose of Islamic law is to legislate punishment, to urge the strengthening of moral responsibility in the same sinner, to admit his sin, so that the side of repentance and acting, reform of himself, and the realization of the servants and the country of goodness and reform, as well as every issue that goes from justice to injustice from mercy to cruelty, and from interest to spoiler, is not from Islam inanything.
4. Raising individuals, educating them, and educating them that the punishment of the perpetrator is his mercy, discipline for his crime, reform for himself, and cleansing of his sins; He said: "Better for her, and if you put me in it, then he did, and the Prophet of God ordered her to do so, and then she complained about her clothes, and then he ordered her, and then he prayed for her, and omar said, "You pray to her, Prophet of God, and you are married?" He said: If i repented, if you were divided among 70 of the people of the city, they would have expanded them, and did there ever find repentance better than having been able to do it for itself to Allah Almighty? (Muslim, D.T.: 1695), (Abu Dawood, D.T.: 4440). Peace be upon him

5. God has the prophet to take care of the lives of Muslims, and not to use violence and murder, such as("The greatest major sins are involving God, self-killing, parental disability, perjury or perjury") (Bukhari, 1987: 5273) and his saying(If the Two Muslims meet with their sword, the murderer and the dead in the fire) said: $\mathrm{O}$ Messenger of God this fight, what about the dead? (He was keen to kill his owner) (Bukhari, 1987: 31), (Al-Suyuti, D.T.: 483). Peace be upon him

6. Raising individuals to be kind treatment, keeping the tongue from ejaculation even if it is his slave; 7: 6858), (Muslim, D.T.: 1660); Peace be upon him

7. The prophet urged him to apply the punishments in the light of Islamic law. 1316, in the punishment of the bomber, Abu Hurra said: "I heard the Messenger of God say: (Whoever slandered his own and he is innocent of what he said is the skin of the Day of Resurrection, except to be as he said)) (Bukhari, 1987: 6858), (Muslim, D.T.: 1660), and in the punishment of the thief cutting off the hand; The Prophet said: (Don't cut off the hand of a thief only in a quarter of a dinar onwards) (Bukhari, 1987), (Muslim, D.T.: 1684), and said(God cursed the thief, steals the egg, 
Al-Sibai, Mustafa (1982), Sunnah and its place in Islamic legislation, Islamic Bureau, Beirut.

Al-Suyuti,

Abdul

RahmanbinAbiBakr (D.T.), Al-Saghir Mosque, Investigation: Mohammed Abdul Rauf bin Taj al-Arifin, Dar Al-Alam, Jeddah.

Al-Dwehi, Ahmed bin Abdullah, al-Rasheed, Ahmed bin Abdulrahman (1432Ah), guide to writing letters and complementary research at Imam Mohammed Bin Saud Islamic University, Riyadh.

- Al-Abadi, Mohammed Hamidan (2004), the values included in the reading book for the first four grades of basic learning (Episode 1) in the Authority of Oman, Arab Gulf Message Magazine, Issue 91, Arab Education Library of the Gulf States.

Al-Ghazali, Abu Hamed Muhammad bin Mohammed (1413 Ah), Al-Masfi in The Science of Origins, Investigation: Mohammed Abdul Salam Abdul Shafi, I1, Scientific Book House, Beirut.

- Ibn Qadama, Abu Mohammed Muwaffaqaldin Abdullah bin Ahmed (1997), singer, C10, Dar Al-Alam alBooks, Riyadh.

- Ibn Al-Kabir, Abu al-Fida Ismail ibn Omar al-Damassi (1401Ah), Interpretation of Ibn Kabir, Dar al-Fikr, Beirut.

Al-Kilani, Jamal Zeid (2014), The Purposes of Punishment in Islamic Law, Al-Najah University Research Journal, Humanities, Volume 28 (1), Palestine.

- Ibn Maja, Abu Abdullah Mohammed binTa'ad al-Qazwini (D.T.), Sinan Ibn Maja, Al-Resala Foundation, Beirut.

Al-Mardi, Abu al-Hassan Ali bin Mohammed bin Habib al-Basri (2006), Royal Al-Qamad, Dar al-Hadith, Cairo.

Muslim, Abu al-Hussein bin alHajjaj al-Qashiri al-Nisaburi (D.T.), Sahih Muslim, Investigation: Mohammed Fouad

\section{Recommendations:}

In light of the results of the research, the researcher recommends:

1. Educational, social and youth institutions adopt the provisions of sanctions in terms of concept and factors that help to achieve it, and this is through the correct understanding of the Qur'an, the Prophet's Sunnah, and the diligence of Muslim scholars.

2. The researcher recommends that all members of society should apply the educational values of the provisions of the law derived from the Holy Quran and the Prophet's Sunnah, for the purpose of preserving justice, equality and peace for the people and the country.

Proposals:

To complete the current research, the researcher presents the following proposals:

1. Conducting a study to reveal the educational values derived from the provisions relating to financial transactions in the Qur'an and the Prophet's Sunnah.

2. Conducting a study on educational values derived from the provisions of the penalties in the Civil Code.

References

The Holy Quran.

- Al-Bukhari, Abdullah Ismail bin Ibrahim (1987), Sahih Al-Bukhari, Investigation: Mustafa Deeb, Dar al-Fikr, Beirut.

Ibn Hazm, Abu Muhammad bin Ali bin Ahmed al-Andalusi (D.T.), Local, Investigation: Arab Heritage Revival Committee, New Horizons House, Beirut.

According to Allah, Ali (1976), Origins of Islamic Legislation, T5, Dar alKnowledge, Cairo.

Abu Daoud, Suleiman bin AlShaath al-Sijistani (D.T.), SinanAbiDaoud, Investigation: Mohammed Mohieddin Abdul Hamid Al-Azdi, J1, Dar al-Fikr, Beirut.

Al-Razi, Mohammed binAbiBakr Abdul Qadir (1983), Mukhtar al-Sabah, Dar al-Resala, Kuwait. 
- Al-Sa'ad, Abu AbdulRahman Ahmed Bin Shabib (1991), Al-Sinan AlKabir, Investigation: Abdul Ghaffar Suleiman al-Bandari, T1, Scientific Books Ho use, Beirut.
Abdel Baki, Heritage Revival House, Beirut.

- Ibn Mansoor, Muhammad ibnMakram al-Ansari (1423 Ah), Tongue of the Arabs, Cairo. 